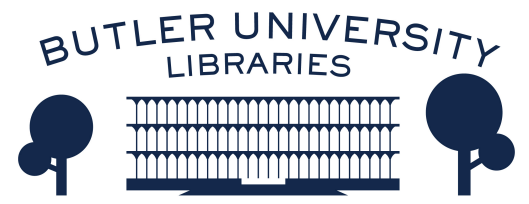

Journal of Hindu-Christian Studies

Volume 15

Article 20

January 2002

\title{
Book Review: "Missionaries, Rebellion and Proto-Nationalism: James Long of Bengal 1814-87"
}

Julius Lipner

Follow this and additional works at: https://digitalcommons.butler.edu/jhcs

Part of the Religion Commons

\section{Recommended Citation}

Lipner, Julius (2002) "Book Review: "Missionaries, Rebellion and Proto-Nationalism: James Long of Bengal 1814-87"," Journal of Hindu-Christian Studies: Vol. 15, Article 20.

Available at: https://doi.org/10.7825/2164-6279.1287

The Journal of Hindu-Christian Studies is a publication of the Society for Hindu-Christian Studies. The digital version is made available by Digital Commons @ Butler University. For questions about the Journal or the Society, please contact cbauman@butler.edu. For more information about Digital Commons @ Butler University, please contact digitalscholarship@butler.edu. 
Vaisnava rather than Saiva view. of divine embodiment, because the former more closely resembles "the Christian theological position with which I grew up and which I have found reasonable and satisfying over the years." (178)

But if there is to be inter-religious theological conversation at all, whether to further the ends of apologetic or of mutual illumination, it is true that reason must be its presupposition and mainstay. Francis Clooney has written the definitive work on this in the context of the Hindu-Christian encounter. The book is therefore indispensable reading for any serious study on the topic.

Bradley Malkovsky

University of Notre Dame

\section{Missionaries, Rebellion and Proto-Nationalism: James Long of Bengal 1814-87. Geoffrey A. Oddie. Surrey: Curzon Press, 1999, $261 \mathrm{pp}$.}

THIS BOOK has an intriguing title. What, you may ask, could James Long, as a British Christian missionary in 19th century colonial Bengal, have to do constructively with "rebellion" and "proto-nationalism"? From this point of view, the heart of the book lies in chapters 7 and 8 , which deal with the (in)famous indigo controversy and its aftermath of the 1860s (incidentally, there should be no apostrophe, as there is repeatedly in this rather poorly copyedited book, before the "s" (viz. "1860's") when periods are mentioned in this way). Long, together with a number of other missionaries of the Protestant church, played a major role in exposing the persistent and brutal exploitation of the local cultivators or ryots by European planters (and many Indian zemindars) in the production of indigo. The point, as I see it, of Oddie's characteristically well-researched though somewhat pedestrian treatment is that by his eventual if brief imprisonment in the ryots' cause, Long not only rebelled with important symbolic undertones against many government officials' and other colonials' expectations of how a missionary should behave, but also became himself something of a rallying point for "proto-nationalist" sentiment among westernised Indians. However, since this last point is not contextualised in any detail in terms of what might pass for the "proto-nationalism" of the times, justification for part of the book's title at any rate must be pronounced to be wanting.

By the time of his trial, Long had come a long way from his privileged origins in Brandon in southern Ireland in the early 19 th century. After an excellent education, rich in the classical and biblical languages, and a conversion to evangelicalism, Long arrived in Calcutta, the centre of the British raj, in 1840 . He was based there until 1872. During these 30 odd years, as Oddie points out in other chapters of his informative book, Long became proficient in the knowledge of Bengali, and equally important, focused his missionary endeavours on seeking to study and improve the lot of rural Bengalis, with special emphasis on education in the vernacular (in contrast, say to an Alexander Duff - whom Long greatly admired - who concentrated on educating the children of more westernised Bengalis in English in the urban context of Calcutta). In this, Long was something of a pioneer, and this emphasis alone is well worth the careful study Oddie has made of him.

Also, both interesting and significant, was Long's preoccupation with what Oddie calls sociological issues, viz. Bengali 
customs and language traits. Long's voluminous writings in this respect gave a boost to a growing fund of knowledge about Bengali culture and played an important role in emphasising a relatively new dimension in mission policy - that of local context for success in propagating a message. Today, one takes what was still a fairly new insight then, for granted.

Long was a sincere and hard-working missionary, with a deep sympathy for the poor and oppressed Bengali, but - and this is thrown up again and again in Oddie's treatment - one feature of his mission seems to taint, to my mind, his selfless dedication: the subjection of all his endeavours to the goal of ultimate conversion of the nonChristians (Hindu and Muslim) among whom he worked, and the undermining of their ancestral faith (first drain the swamp, he said memorably, referring thus unfavourably to non-Christian religion, before you sow the good seed in it). This introduced a note of spiritual calculation in all he did. Not for him the task of labouring for the good per se of the non-Christian, irrespective of the outcome, that is, love for love's sake, "witness" simply in truth's cause as he saw it. Rather, it was love for an ulterior motive: the pulling in of souls; not for the non-Christian's own sake, but for the sake of the non-Christian qua potential Christian. Today, increasingly in some mission-discourse thankfully, mission goals have a greater purity of intention: labour selflessly in God's cause, and leave it to God to give fruit as he/she sees fit. Long's ulterior motive applied equally to his visits to Russia in later life. He wanted Russian British co-operation to check the growth of Islam in their Asian empires so that the expansion of Christianity might be the more unopposed. Islam or Hinduism, for that matter, had not much salvific or humanising worth in their own right.

This is where I find Oddie's provocative point that the critique of the Orientalist viewpoint (which, he says, seems to have overlooked missionary colonial witness) does not in fact apply to that witness, seriously flawed (ch. 11). According to Oddie, if Orientalism is "the corporate institution for dealing with the Orient ... for dominating, restructuring, and having authority" over it (180), then missionary witness was not generally Orientalist, for "the dichotomy of ultimate importance" for Evangelicals and other Europeans with a deeply Christian view of the world, "was not Europe versus the Orient, but the saved versus the damned" (181), and this distinction transcended cultural circumstances.

But this is seriously to oversimplify the issue. For, as we have seen in the case of Long (by no means a rampant Evangelical), deeply-held Christian views of the world at the time, at least among Europeans, tended systematically to undermine non-Christian traditions as salvifically inadequate (after all, in Long's words, they were a "swamp" that needed draining of its pernicious influences) so as to supplant them with or superimpose on them the Christian message, embedded as it was in western culture. Surely this must - and did - encourage Orientalist strategies.

Through his various works, Oddie has made an outstanding contribution to our understanding of the role of religion in colonial South Asia, and this book is an illustrious addition to that corpus. It is to be highly recommended for filling an important gap in the literature.

Julius Lipner University of Cambridge 